\title{
DETERMINATION OF THE SILAGE QUALITY CHARACTERISTICS OF DIFFERENT SWITCHGRASS (PANICUM VIRGATUM L.) CULTIVARS
}

\author{
ELİş, S. - ÖZYAZICI, M. A.* \\ Department of Field Crops, Faculty of Agriculture, Siirt University, Siirt, Turkey \\ ${ }^{*}$ Corresponding author \\ e-mail: arifozyazici@siirt.edu.tr; phone: +90-532-633-4592 \\ (Received $10^{\text {th }}$ Sep 2019; accepted $14^{\text {th }}$ Nov 2019)
}

\begin{abstract}
This study was carried out to determine the silage quality characteristics of some switchgrass (Panicum virgatum L.) cultivars. Kanlow, Shelter, Shawnee, BoMaster, Alamo, Trailblazer, Cave in Rock and Long Island cultivars of switchgrass constituted the plant material of the study. For silage purposes, the plants were harvested 10-15 days after reaching the flowering period. The harvested plants were allowed to ferment for 70 days. According to the results, the silage of switchgrass cultivars was statistically significantly at $\mathrm{p}<0.01$ level for both physical and chemical properties. In the study, $\mathrm{pH}$ content, the dry matter, lactic acid, butyric acid, acetic acid, crude protein, acid detergent fiber, and neutral detergent fiber ratios of the silage of switchgrass cultivars varied between 3.84-4.86, 39.0-51.0\%, $1.78-2.35 \%, 0.05-0.33 \%, 0.35-1.55 \%, 3.76-5.57 \%, 39.30-41.73 \%$, and $70.96-75.41 \%$, respectively. In terms of the Fleig score, it was determined that the quality of the silage obtained from switchgrass cultivars could be classified as "very good". According to result, it was determined that BoMaster, Alamo, and Trailblazer cultivars, especially Long Island and Cave in Rock cultivars of switchgrass that came to the forefront in terms of silage quality, could be successfully used in silage production.
\end{abstract}

Keywords: switchgrass, physical properties, acetic acid, lactic acid, butyric acid

\section{Introduction}

Switchgrass (Panicum virgatum L.) is a perennial warm-season $\mathrm{C} 4$ plant, which is one of the grass species specific to North American meadows (McLaughlin and Kszos, 2005; Missaoui et al., 2006; Jiang et al., 2019). It is used as an energy plant in the United States, Canada, and some European countries (Elbersen et al., 2001; Casler and Boe, 2003; Belanger et al., 2012). Furthermore, it is also an important species used for many purposes such as soil and water conservation, grazing and forage (Sanderson et al., 1999; Muir et al., 2001; Vogel et al., 2002; Vogel, 2004; Lee et al., 2007; Sanderson and Burns, 2010; Belanger et al., 2012; Jiang et al., 2019). In the studies carried out, it were reported that high yield and high-quality feed was obtained from some genotypes of switchgrass, and it had the potential to be used as an animal feed (Ameen et al., 2018; Davis et al., 2018; Milenković et al., 2018; Sena et al., 2018).

Few studies were conducted on switchgrass, which is a new plant for Turkey. In this sense, the first basic information about the growing techniques of switchgrass was produced within the scope of the TUBITAK project developed by Soylu et al. (2010). Within the scope of that project, adaptation studies were conducted on switchgrass cultivars as an introductory material in the Central Anatolia Region with an arid and/or semi-arid climate in Turkey, and the cultivars suitable for Turkey were determined. Within the scope of the same study, the necessary information about the growing techniques of high-performance switchgrass cultivars from planting to harvest in Turkey, and their potential to be utilized as a bio-fuel was obtained (Soylu, 2012). As a 
result of these studies carried out by Soylu et al. (2010), it was emphasized that the facts that the switchgrass cultivars examined yielded a green biomass in quantities ranging 60-70 tons/ha, that dry matter ratios ranged between 31.84-40.97\% during the flowering period, the protein ratio in green biomass increased up to $9-10 \%$ in many cultivars, and acid detergent fiber (ADF) and neutral detergent fiber (NDF) values revealed positive results regarding the consumption and digestibility of the feed to be obtained from this plant were the indications that the silage quality of switchgrass plant would also be high, and it was reported that switchgrass plant had a high economic growing potential especially for silage purposes.

The studies carried out around the world mostly focused on the bioenergy value (Brodowska et al., 2018; Kimura et al., 2018), adaptation (Ma et al., 2011), morphological and biological properties (Brunken and Estes, 1975), forage yield (Wolf and Fiske, 1995; Kimura et al., 2018) and biomass yield (Sanderson et al., 1999; Piscioneri et al., 2001; Lemus et al., 2002; Kimura et al., 2018), genetics and genetic variation (Quinn, 1969; Hopkins et al., 1995, 1996; Quinn and Wetherington, 2002) of switchgrass. There are very few studies on the silage and silage quality of switchgrass.

On the other hand, in silage plant production, it is possible to obtain high quality and high yield by the cultivation of varieties suitable for ecologies. In this sense, the selection of variety is also an important cultural practice to achieve a sustainable yield from plant production (Ileri et al., 2018). Undoubtfully, the difference of cultivars, as well as the factors such as climate and soil factors, cultural practices, and harvesting period, significantly affects the silage quality. This study was carried out to determine the silage quality of some switchgrass (Panicum virgatum L.) cultivars.

\section{Materials and methods}

\section{Silage material and growing conditions}

The plant material of the study consisted of Kanlow, Shelter, Shawnee, BoMaster, Alamo, Trailblazer, Cave in Rock, and Long Island cultivars of switchgrass. In the study, the plant materials of the second year (2017) of switchgrass cultivars established on July 10, 2015, under the conditions of Siirt province (Figure 1), which is located in the Southeastern Anatolia Region of Turkey with a semi-arid climate, were used for silage purposes.

According to long-term (1960-2017) meteorological data (Anonymous, 2017) of the Siirt province, the current climate in the region is semi-arid. Summers are warmer than winters (the average temperature in July is 30.6 and in January is $2.8^{\circ} \mathrm{C}$ ). The mean annual temperature, rainfall, and evapotranspiration are $16.2^{\circ} \mathrm{C}, 691.4 \mathrm{~mm}$, and $937.5 \mathrm{~mm}$, respectively. According to the soil climate regime of the Newhall simulation model (Van Wambeke, 2000), it was determined that the study site has a thermic soil temperature regime and xeric (dry xeric in the subgroup) soil moisture regime (Figure 2).

Some physical and chemical properties of the soils where the switchgrass is grown are given in Table 1. Organic matter content of soil was determined according to Nelson and Sommers (1982) and other parameters were determined according to Anonymous (1992). The soils where switchgrass is grown are clayey textured, salt-free, slightly alkaline and have moderate lime content, less organic matter and available phosphorus (P) coverage, and high available potassium (K) content (Table 1). 
In the study, the field experiment was established according to the randomized block experimental design with 4 replications. In sowing, row spacing was $20 \mathrm{~cm}$, and the number of rows in a parcel was 10. Sowing was performed so that there would be 400 live seeds per square meter. Before sowing, diammonium phosphate (18-46-0\%, N-P-K) fertilizer was applied equally to each parcel with the calculation of $100 \mathrm{~kg} / \mathrm{ha}$ pure $\mathrm{P}_{2} \mathrm{O}_{5}$ according to the soil analysis results. A drip irrigation system was established immediately after sowing, and irrigation was performed. When plants were $10-15 \mathrm{~cm}$, ammonium nitrate $(33 \% \mathrm{~N})$ fertilizer was given equally to each parcel with the calculation of $60 \mathrm{~kg} / \mathrm{ha}$ pure nitrogen $(\mathrm{N})$ (Figure 3 ).

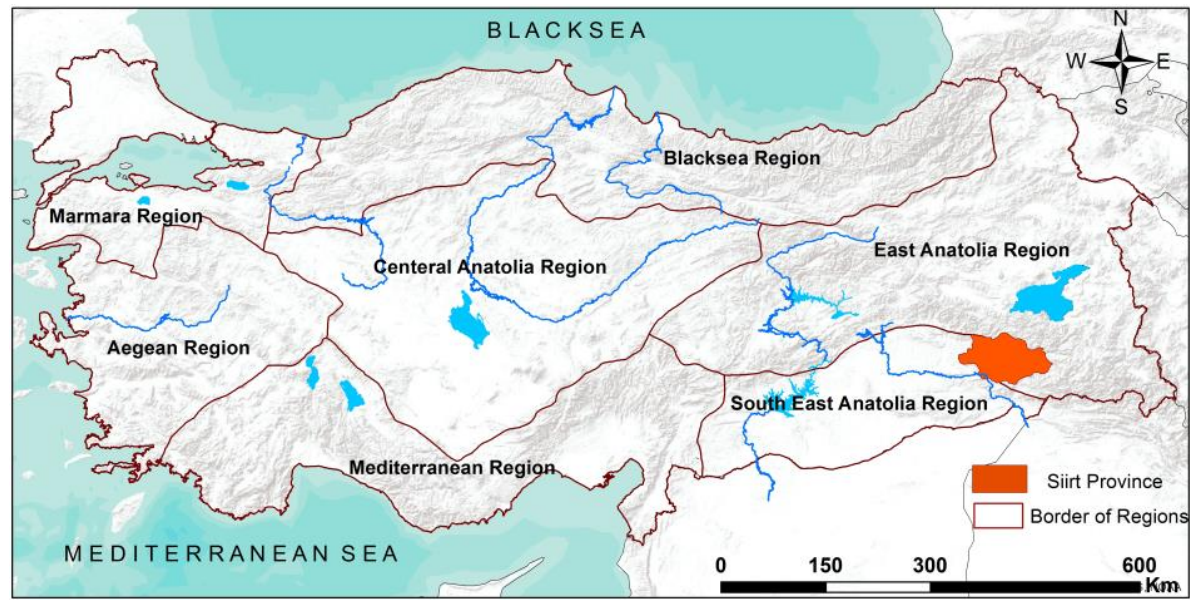

Figure 1. The location where silaged switchgrass cultivars are grown

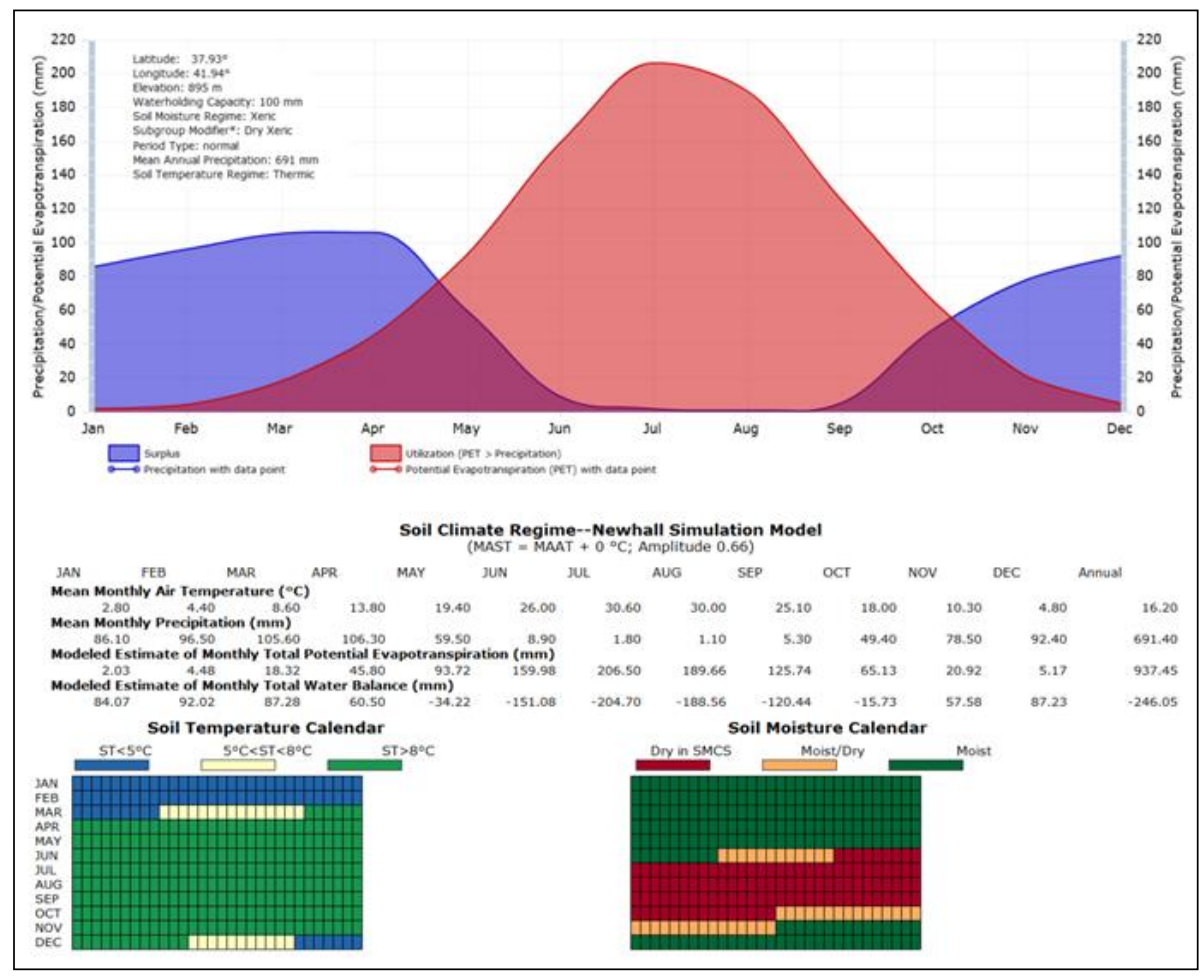

Figure 2. Soil moisture and temperature regime diagrams according to the Newhall simulation model 
Table 1. Some physical and chemical properties of the soils where switchgrass is grown $(0-20 \mathrm{~cm})^{*}$

\begin{tabular}{c|c}
\hline Parameters & Value \\
\hline Clay, \% & 55.84 \\
Sand, \% & 36.26 \\
Silt, \% & 7.90 \\
$\mathrm{pH}$ & 7.98 \\
Electrical conductivity (EC), $\mathrm{mS} \mathrm{cm}^{-1}$ & 0.363 \\
Calcareous $(\mathrm{CaCO}) \%$ & 13.0 \\
Organic matter, \% & 1.31 \\
Available $\mathrm{P}, \mathrm{kg} \mathrm{P}_{2} \mathrm{O}_{5} \mathrm{ha}^{-1}$ & 43 \\
Available K, $\mathrm{kg} \mathrm{K}_{2} \mathrm{O}^{-1}$ & 1150 \\
\hline
\end{tabular}

*: The analyzes were carried out in the laboratory of Black Sea Agricultural Research Institute
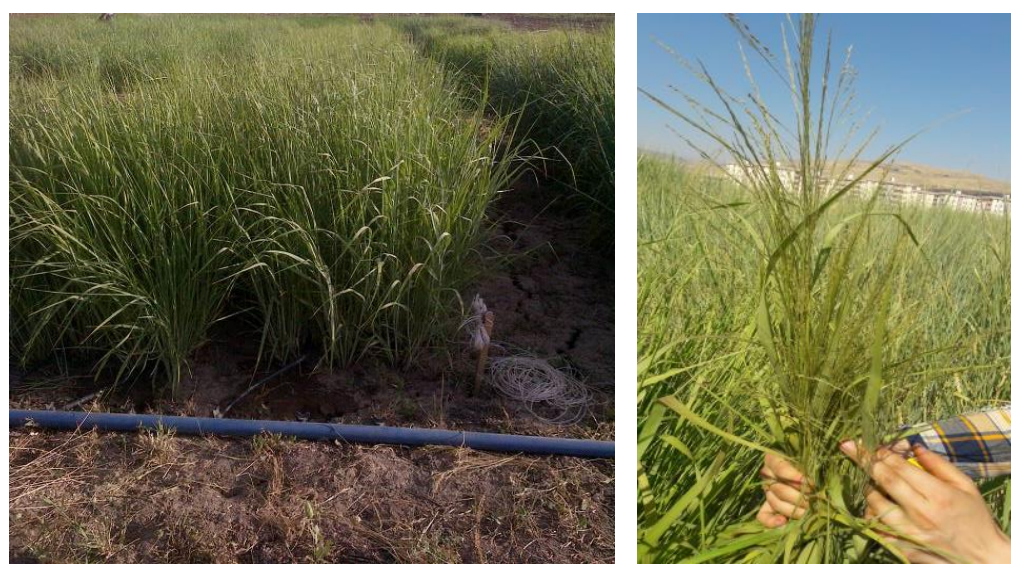

Figure 3. Switchgrass experimental site and harvest

\section{Silage making technique}

For silage purposes, switchgrass cultivars were harvested separately for each parcel 10-15 days after reaching the flowering period (Soylu, 2012). The harvested plants were brought to the laboratory environment, and all green plant materials were manually chopped into $0.5-1 \mathrm{~cm}$ sizes with a knife. The chopped plant particles were mixed with $0.5 \%$ table salt $(\mathrm{NaCl})$ for protection purposes (K1lıç, 1986; Geren et al., 2011). Then, the material of each parcel was filled in 3-liter glass jars by pressing well in accordance with the sequential filling technique (Petterson, 1988), and the lid borders of the jars tightly closed with silicone plastic lids were wrapped with thick packaging tape for 3-4 rounds for airtightness. The silage jars prepared in this way were allowed to ferment for 70 days at room temperature in a dark environment.

\section{Physical and chemical analysis methods of silage samples}

After the fermentation process was completed, the matured silage was opened, a $3-4 \mathrm{~cm}$ portion was discarded from the cap opening, and then physical and chemical analyses were performed in the remaining silage samples.

In the samples taken to represent the mass in the opened silage jars, physical examinations such as odor, structure, and color were subjectively performed by three subject matter experts. The evaluation of physical analyses was based on the scoring 
method developed by Anonymous (1987). The silage quality class according to the physical properties of the silage was determined by the DLG (Deutsche Landwirtschafts-Gesellschaft) score (Table 2). The DLG score is the total physical score (0-20 points) obtained from the sum of odor, structure, and color scores (Aky1ldiz, 1984; Anonymous, 1987; Ergün et al., 2013).

Table 2. Physical examination key developed by DLG and silage quality class

\begin{tabular}{l|c}
\hline \multicolumn{1}{c}{ Physical examination key } & Score \\
\hline 1. Odor & 14 \\
\hline No butter acid odor, slightly sour, fruity and aromatic odor & 8 \\
A small amount of butter acid, strong sour odor, and slight escalation & 4 \\
Moderate butter acid odor, strong escalation-musty odor & 2 \\
Strong butter acid or ammonia odor, very slight sour odor & 0 \\
Strong decomposition, ammonia or musty odor & 4 \\
\hline 2. Structure & 2 \\
\hline Intact leaves and stems & 1 \\
A slightly deteriorated structure of leaves & 0 \\
A deteriorated structure of leaves and stems, musty and dirty & 2 \\
Rotten Leaf and Stalk & 1 \\
\hline 3. Color & 0 \\
\hline Preserved its color at the moment it was silaged (brown in withered silage) & DLG score \\
Slightly changed color (yellow to brown) & $20-18$ \\
Completely changed color (reseda green) & $17-14$ \\
\hline \multicolumn{1}{c}{ Quality class according to the physical properties of silage } \\
\hline Quality class & $13-10$ \\
\hline I- Very good & $9-5$ \\
II- Good & $4-0$ \\
III- Medium & \\
IV- Low (low value) & \\
V- Corrupted (useless) & \\
\hline
\end{tabular}

Some silage material was taken from each silage jar to represent the jar and mixed homogeneously, and $25 \mathrm{~g}$ of the wet silage sample of this mixture was weighed on the precision balance and placed in the mixer. $250 \mathrm{ml}$ of distilled water was added to the sample, and it was mixed for 10 minutes, then filtered through filter paper (Whatman ${ }^{\mathrm{TM}}$ No. 1441-125, GE Healthcare Life Sciences, Marlborough, MA, USA), and pH was determined by means of a $\mathrm{pH}$ meter in a $200 \mathrm{ml}$ strainer taken into glass beakers (Anonymous, 1993). Lactic acid (LA), acetic acid (AA), and butyric acid (BA) were determined using high-performance liquid chromatography (HPLC) as per the methods of Canale et al. (1984). $300 \mathrm{~g}$ of the wet sample was taken from matured silage separately in each silage jar, and it was dried in an oven at $70^{\circ} \mathrm{C}$ for 48 hours. Dried silage samples were weighed on the precision balance, and their weights were determined, and the dry matter (DM) ratio was determined by proportioning to wet weight (Bulgurlu and Ergül, 1978).

The dried silage samples were ground separately for each jar. The ADF, NDF, and crude protein (CP) ratios in the ground samples were determined by NIRS (Near Infrared Reflectance Spectroscopy) and \#IC-0904FE calibration set (Anonymous, 2018) in the laboratory of Ondokuz Mayıs University Faculty of Agriculture Department of Field Crops (Brogna et al., 2009). 


\section{Quality of silage according to the Fleig score}

One of the most common methods used to determine the silage quality practically is the Fleig score (FS), which is determined by using the relationship between the DM content and $\mathrm{pH}$ value of silage. FS was calculated using Equation 1 created by DLG (Anonymous, 1987).

$$
\mathrm{FS}=[220+(2 \mathrm{x} \text { silage } \mathrm{DM} \text { ratio }-15)]-40 \mathrm{x} \text { silage } \mathrm{pH} \text { value }
$$

Considering the FS values obtained from the above-mentioned equation, the silage quality class was evaluated according to the score criteria presented in Table 3.

Table 3. Quality classes of silo feeds according to FS (Anonymous, 1987)

\begin{tabular}{c|c}
\hline Calculated FS & Silage quality class \\
\hline $100-81$ & I- Very good \\
$80-61$ & II- Good \\
$60-41$ & III- Satisfactory (Medium) \\
$40-21$ & IV- Low (low value) \\
$20-0$ & V- Bad \\
\hline
\end{tabular}

\section{Statistical analyses}

The data obtained from the study were subjected to the analysis of variance according to the randomized block experimental design. The differences between the groups according to the F-test results were determined by Tukey's multiple comparison test (Açıkgöz and Açıkgöz, 2001).

\section{Results and discussion}

\section{Silage dry matter ratio of switchgrass cultivars and some chemical properties of silage}

\section{Silage dry matter ratio}

The DM ratio has great importance in the full realization of chemical events during silage formation, and this ratio is the most important quality criterion used in the determination of silage quality (Geren, 2001; Çakmak et al., 2013). In the study, the highest DM ratio was found in the Alamo, BoMaster, Kanlow, Trailblazer, and Cave in Rock switchgrass cultivars that statistically constituted the first group. The DM ratios of these cultivars varied between 47.3-51.0\%. The lowest DM ratio was found in the silage of Shawnee and Long Island cultivars by $39.0 \%$ and $39.7 \%$, respectively. This difference between the cultivars in terms of the silage DM ratio was found to be statistically significant at $\mathrm{p}<0.01$ level (Table 4). The reason for this difference between the cultivars can be explained by different amounts of DM they can produce by their genetic capacity. Furthermore, it is considered that the difference in the silage DM ratio between the cultivars was also affected by the difference in DM losses, caused by chemical events in the fermentation process, according to cultivars. While Luginbuhl et al. (2000) reported that the silage DM ratio was $27.2 \%$ in Kanlow switchgrass cultivar, Cassida et al. (2005) reported that the DM ratio in switchgrass varied between 39.4-45.1\%, and Zhao et al. (2017) reported that the DM ratio varied between $24.68-26.43 \%$. It is considered that the fact that the DM ratios determined in our study 
were different from those reported in the literature was affected by different genotype, harvest time, and growing conditions.

On the other hand, in the adaptation study carried out by Soylu et al. (2010) with 9 switchgrass cultivars (Alamo, Forestburg, Cave in Rock, Carthage, Shelter, Dacotah, Blackwell, Shawnee, and Kanlow) under irrigated conditions in the Central Anatolia Region of Turkey, they reported that the DM ratios of cultivars varied between $31.84 \%-40.97 \%$ and that the DM ratio of above $30 \%$ in switchgrass cultivars was extremely important in terms of use both for silage and directly in animal feeding. Accordingly, although the DM ratio among cultivars varies, a high DM ratio is important for silage quality. Indeed, while Çayıroğlu et al. (2016) reported that the DM content of silage material was an important factor affecting aerobic stability, Filya et al. (2000) reported that the aerobic stability of silage made with the material with a low DM content decreased, and Barnes et al. (1995) and Mohd-Setapar et al. (2012) reported that the DM contents of the material to be silaged for good quality silage and/or successful fermentation should be between $28-42 \%$ and $25-40 \%$, respectively. In view of these values reported by the researchers, it was observed that all switchgrass cultivars contained quite sufficient DM.

Table 4. Values of the DM ratio and some chemical properties of silage obtained from switchgrass cultivars*

\begin{tabular}{c|c|c|c|c|c|c|c|c}
\hline Cultivars & $\begin{array}{c}\text { DM } \\
(\boldsymbol{\%})\end{array}$ & $\begin{array}{c}\text { LA } \\
(\boldsymbol{\%})\end{array}$ & $\begin{array}{c}\text { BA } \\
(\boldsymbol{\%})\end{array}$ & $\begin{array}{c}\text { AA } \\
(\boldsymbol{\%})\end{array}$ & $\mathbf{p H}$ & $\begin{array}{c}\text { CP } \\
(\boldsymbol{\%})\end{array}$ & $\begin{array}{c}\text { ADF } \\
(\boldsymbol{\%})\end{array}$ & $\begin{array}{c}\text { NDF } \\
(\boldsymbol{\%})\end{array}$ \\
\hline Kanlow & $48.0 \mathrm{a}$ & $1.78 \mathrm{~b}$ & $0.33 \mathrm{a}$ & $1.29 \mathrm{ab}$ & $4.73 \mathrm{a}$ & $4.35 \mathrm{bc}$ & 41.20 & $75.41 \mathrm{a}$ \\
Shelter & $44.7 \mathrm{ab}$ & $1.96 \mathrm{ab}$ & $0.29 \mathrm{a}$ & $1.02 \mathrm{ab}$ & $4.72 \mathrm{a}$ & $3.76 \mathrm{c}$ & 41.73 & $73.56 \mathrm{abc}$ \\
Shawnee & $39.0 \mathrm{~b}$ & $1.99 \mathrm{ab}$ & $0.21 \mathrm{ab}$ & $1.55 \mathrm{a}$ & $4.86 \mathrm{a}$ & $4.72 \mathrm{abc}$ & 39.30 & $70.96 \mathrm{c}$ \\
BoMaster & $48.7 \mathrm{a}$ & $2.22 \mathrm{a}$ & $0.08 \mathrm{~b}$ & $0.45 \mathrm{~b}$ & $3.94 \mathrm{bcd}$ & $4.53 \mathrm{abc}$ & 40.33 & $75.25 \mathrm{a}$ \\
Alamo & $51.0 \mathrm{a}$ & $1.94 \mathrm{ab}$ & $0.12 \mathrm{~b}$ & $1.33 \mathrm{ab}$ & $4.32 \mathrm{~b}$ & $4.23 \mathrm{bc}$ & 40.77 & $73.71 \mathrm{ab}$ \\
Trailblazer & $47.7 \mathrm{a}$ & $2.01 \mathrm{ab}$ & $0.13 \mathrm{~b}$ & $0.65 \mathrm{ab}$ & $4.24 \mathrm{bc}$ & $5.33 \mathrm{ab}$ & 40.57 & $71.54 \mathrm{bc}$ \\
Cave in Rock & $47.3 \mathrm{a}$ & $2.05 \mathrm{ab}$ & $0.08 \mathrm{~b}$ & $0.62 \mathrm{ab}$ & $3.88 \mathrm{~cd}$ & $5.23 \mathrm{ab}$ & 40.72 & $72.86 \mathrm{abc}$ \\
Long Island & $39.7 \mathrm{~b}$ & $2.35 \mathrm{a}$ & $0.05 \mathrm{~b}$ & $0.35 \mathrm{~b}$ & $3.84 \mathrm{~d}$ & $5.57 \mathrm{a}$ & 40.59 & $73.17 \mathrm{abc}$ \\
\hline$F_{\text {cultivar }}$ & $9.698^{* *}$ & $4.524^{* *}$ & $10.365^{* *}$ & $4.931^{* *}$ & $27.695^{* *}$ & $7.210^{* *}$ & 0.831 & $9.054^{* *}$ \\
\hline CV $(\%)$ & 5.26 & 6.98 & 34.38 & 38.79 & 3.13 & 8.49 & 3.25 & 1.24 \\
\hline
\end{tabular}

*: The difference between the means indicated by the same letter in the same column is not significant,

${ }^{* *}: \mathrm{p}<0.01$ is significant within error limits, CV: Coefficient variation

No study was found on the silage characteristics of cultivars in switchgrass plant. Therefore, in view of the silage studies carried out with corn plant which is a physiologically $\mathrm{C} 4$ plant such as switchgrass, it was reported that there were significant differences between the cultivars in terms of DM, similarly to the results of our study, and that the DM ratio according to cultivars in corn silage varied between 18.35\%-30.72\% (Özdüven et al., 2009), 25.30\%-31.58\% (Güney et al., 2010), 20.3\%-28.1\% (Seydoşoğlu, 2017), 20.57\%-23.35\% (Ileri et al., 2018).

\section{Lactic acid (LA) content of silage}

The amount and composition of organic acids such as LA formed during silage fermentation determine the quality of fermentation, and LA is one of the main preservative organic acids in the silage (Filya, 2001). According to the results of statistical analysis, it was determined that the LA contents of the silage obtained from switchgrass cultivars showed significant differences $(\mathrm{p}<0.01)$. The most distinctive 
difference was between Kanlow and all other cultivars. The highest LA ratio was found in the Long Island (2.35\%) and BoMaster (2.22\%) cultivars that were statistically included in the first group (Table 4).

It was reported that the LA ratio should be above $2.00 \%$ in high-quality silage feeds (Kılıç, 1986; McDonald et al., 1991; Alçiçek and Özkan, 1997; Weinberg and Ashbell, 2003) and that a high LA ratio was the assurance of a healthy fermentation (Johnson and Harrison, 2001). According to the results of our study (Table 4), it was found out that the LA values found in the Long Island, BoMaster, Cave in Rock, and Trailblazer silage of switchgrass cultivars were above the reference value and included in the highquality silage group. In the silage made with corn and sorghum cultivars, it was reported that the LA ratio varied between $1.58 \%-8.57 \%$ by Reeves et al. (1989), 2.6\%-3.1\% by Hart (1990), $0.67 \%-2.35 \%$ by Geren and Kavut (2009), and $7.64 \%-12.33 \%$ by Seydoşoğlu (2017) depending on the maturity period.

\section{Butyric acid (BA) content of silage}

An important parameter in the determination of silage quality by analytical methods is the BA, which negatively affects silage quality (Geren and Kavut, 2009). In a quality silage feed obtained as a result of a good fermentation, the fact that BA was generally between $0.1-0.7 \%$ was considered to be normal although it was undesirable (Woolfort, 1984; Weinberg and Ashbell, 2003). On the other hand, Catchpoole and Henzell (1971) reported that the BA concentration in quality silage was less than $0.2 \%$. When the data of our study were examined, it was observed that the BA content of the silage of switchgrass cultivars varied between $0.05-0.33 \%$ and that the BA content of all silaged switchgrass cultivars was within acceptable limits. Nevertheless, the difference between the cultivars in terms of BA was found to be statistically significant at $\mathrm{p}<0.01$ level, and the BA ratios of Kanlow (0.33\%), Shelter $(0.29 \%)$, and Shawnee $(0.21 \%)$ silage were higher than other cultivars (Table 4). It can be explained by the limited propagation and activity of LA bacteria during fermentation and/or the degradation of LA into BA, as it was indicated by Bolsen et al. (1996). Indeed, as it is seen in Table 4, the low LA values of the cultivars with a high BA ratio confirm this situation.

In the studies carried out with corn silage, the BA ratio was determined to be $0.07 \%$ (Phillip and Hidalgo, 1989) and 0.08\% (Deswysen et al., 1993). On the contrary, while Geren and Kavut (2009) and Arslan et al. (2017) reported that the BA value was not measured in sorghum and corn silage and sorghum silage, respectively; Hart (1990) reported that the BA value varied between $0.006 \%$ and $0.037 \%$ in the sorghum silage, and Reeves et al. (1989) reported that the BA value varied between $0.06 \%$ and $0.43 \%$ in the corn silage. In our study, it is possible to say that the BA values determined in the silage of switchgrass cultivars were compatible with these values in the literature determined in corn and sorghum silage, which are $\mathrm{C} 4$ plants like switchgrass.

\section{Acetic acid $(A A)$ content of silage}

When the AA ratios of the silage obtained from switchgrass cultivars were examined, the highest AA ratio was found to be $1.55 \%$ in Shawnee cultivar, and the difference in terms of AA between Shawnee cultivar and Kanlow, Shelter, Alamo, Trailblazer, and Cave in Rock cultivars was found to be insignificant. The lowest AA content was determined in Long Island $(0.35 \%)$ and BoMaster $(0.45 \%)$ cultivars. This difference between the cultivars was statistically significant at $\mathrm{p}<0.01$ level (Table 4). While Weinberg and Ashbell (2003) reported that the AA ratio should be less than $0.8 \%$ in the 
silage feed as a result of a good fermentation, McDonald et al. (1991) and Alçiçek and Özkan (1997) reported that the AA ratio should be between 0.3-0.7\%. When these values reported in the literature are taken into consideration, it is possible to say that the AA ratios of the silage of BoMaster, Trailblazer, Cave in Rock, and Long Island switchgrass cultivars were below the critical value.

It was reported that the AA ratio varied between $0.6-1.42 \%$ in the sorghum silage (Hart, 1990; Arslan and Çakmakç1, 2011; Arslan et al., 2017) and between 0.2-3.71\% in the corn silage (Phillip and Hidalgo, 1989; Reeves et al., 1989; Deswysen et al., 1993; Sucu and Filya, 2006). These results obtained from sorghum and corn silage, which are physiologically included in the $\mathrm{C} 4$ group such as switchgrass, were similar to the results of our study.

\section{pH of silage}

$\mathrm{pH}$ formed during silage fermentation is one of the most important parameters determining the quality of fermentation (Kiermeier and Renner, 1963; Filya, 2001). In our study, a statistically significant difference at $p<0.01$ level was found in terms of the $\mathrm{pH}$ of silage between switchgrass cultivars. The lowest silage $\mathrm{pH}$ value was found to be 3.84 in the Long Island switchgrass cultivar. The highest silage $\mathrm{pH}$ value was found in the Shawnee (4.86), Kanlow (4.73), and Shelter (4.72) cultivars that were statistically included in the same group (Table 4). The difference in terms of $\mathrm{pH}$ between cultivars can be explained by the fact that LA production varies by cultivars. In other words, as it is seen in Table 4, the silage $\mathrm{pH}$ was found to be low in the cultivars with a high LA ratio. This decrease in $\mathrm{pH}$ was due to the accumulation of LA. Indeed, Ohmomo et al. (1995) reported that it was important that $\mathrm{pH}$ was less than 4.2 in silage fermentation, which was possible with the efficient production of LA from sugar in a silo.

The way to remove odors, prevent spoilage, and protect nutrients in silage feeds is to make silage protected by good fermentation. Protection is based on high acidity depending on LA formation (Isnandar et al., 2010). Furthermore, low pH may also prevent the growth of parasites and some pathogenic microorganisms (Göhl, 1981). Church (1986) and Ergün et al. (2013) reported that the optimum $\mathrm{pH}$ range for the growth of milk acid bacteria growing in the acid medium was 3.8-4.2 and that bacteria causing spoilage and decomposition did not live in the silage with a value in this $\mathrm{pH}$ range. Some other researchers (Danley et al., 1973; Comberg, 1974; K1lıç, 1986; Roth, 2001; Açıkgöz et al., 2002; Kılıç, 2006) reported that the $\mathrm{pH}$ value of very good silage was between 3.5 and 4.5. It can be said that Long Island, Cave in Rock, BoMaster, Alamo, and Trailblazer from switchgrass cultivars were within the appropriate limits in terms of silage $\mathrm{pH}$. Therefore, a successful fermentation process took place in the silage formation process, especially with respect to these cultivars. While Belanger et al. (2012) reported that $\mathrm{pH}$ varied between 4.0-4.3 in the switchgrass silage, Zhao et al. (2017) reported that the $\mathrm{pH}$ value was 5.4 in the 30-day silaged switchgrass material.

In the studies carried out on corn and sorghum cultivars that are $\mathrm{C} 4$ plant such as switchgrass, it was reported that the silage $\mathrm{pH}$ value was different between the cultivars and the $\mathrm{pH}$ value ranged between 3.03-5.20 (Hart, 1990; Deswysen et al., 1993; Geren, 2000, 2001; Kavut and Soya, 2012; Canbolat et al., 2016; Seydoşoğlu, 2017; Ileri et al., 2018). 


\section{Crude protein $(C P)$ ratio in silage}

A statistically significant difference at $\mathrm{p}<0.01$ level was found between switchgrass cultivars in terms of the $\mathrm{CP}$ ratio. While the highest $\mathrm{CP}$ ratio was found to be $5.57 \%$ in the Long Island silage, the difference between the Long Island, Shawnee, BoMaster, Trailblazer, and Cave in Rock cultivars in terms of the CP ratio was found to be statistically insignificant. The lowest silage $\mathrm{CP}$ ratio was found in the Shelter cultivar by $3.76 \%$ (Table 4). The CP ratio emerges a result of the genetic and morphological characteristics of plants (Güney et al., 2010). Therefore, it is possible to say that it is an expected result that there are significant differences between the cultivars with different properties. Indeed, in some studies carried out with the corn plant (Seydoşoğlu, 2017; Ileri et al., 2018), it was also reported that cultivars had a significant effect on the silage CP content.

It was observed that the $\mathrm{CP}$ ratio values determined in the silage of switchgrass cultivars were consistent with the results of Sanderson et al. (1999) and Mantino et al. (2017), slightly higher than the data of Cassida et al. (2005), and lower than the values obtained by Anderson et al. (1988), Soylu et al. (2010), Çiçek (2017), and Mohammed and Desta (2017). Milenković et al. (2018) reported that the CP ratio of switchgrass cultivars varied between $5.62 \%$ (Alamo) and $8.74 \%$ (Kanlov). The difference between the values obtained in our study and the literature in terms of the $\mathrm{CP}$ ratio can be explained by different ecologies, cultural processes, and genotypic structures of plants.

In the silage made with the corn plant which is a $\mathrm{C} 4$ plant like switchgrass, $\mathrm{CP}$ values varied between 5.01\%-10.63\% (Filya, 2001; Polat et al., 2005; Güney et al., 2010; Çakmak et al., 2013; Rafiuddin et al., 2016).

\section{Silage acid detergent fiber $(A D F)$ and neutral detergent fiber $(N D F)$ ratio}

The difference between switchgrass cultivars in terms of the ADF ratio was found to be statistically insignificant. However, the NDF ratio showed a statistically significant difference at the level of $\mathrm{p}<0.01$ between the cultivars. The ADF ratio of silage varied between 39.30-41.73\%. The lowest NDF ratio was found in the Shawnee cultivar by 70.96\%. The highest NDF ratio was found in the Kanlow (75.41\%) and BoMaster $(75.25 \%)$ cultivars that statistically constituted the first group. Nevertheless, a statistically significant difference in terms of the NDF ratio was between the Shawnee and Trailblazer cultivars and other cultivars (Table 4). This difference between the cultivars in terms of NDF can be explained by different temperature, moisture, and fertilizer utilization during the period from sowing-time to harvest.

The ADF and NDF ratios, which are the plant cell wall components, are a good indicator of total digestible nutrients, and the ADF and NDF ratios are desired to be low in roughage (Van Soest, 1994; Gürsoy and Macit, 2014). When the roughage quality standard for farm animals $(<31 \%=$ top quality, $31-35 \%=$ very good, $36-40 \%=$ good, $41-42 \%=$ medium, $43-45 \%=$ bad and $>45 \%=$ unacceptable for ADF; $<40 \%=$ top quality, $40-46 \%=$ very good, $47-53 \%=$ good, $54-60 \%=$ medium, $61-65 \%=$ bad and $>65 \%=$ unacceptable for NDF) reported by Rohweder et al. (1978) is considered, it can be said that the silage of switchgrass cultivars was of good and/or medium quality in terms of the ADF ratio and unacceptable in terms of the NDF ratio. The fact that the NDF ratio, which expresses the whole fiber including hemicellulose, cellulose, and fiber in the plant, was high in the silage of switchgrass cultivars is considered to be due to the slowdown of the degradability of cell wall agents such as NDF as a result of the low 
number of LA bacteria in the silage medium although some cultivars were slightly more than $2 \%$ (Table 4), as it was also indicated by Filya (2001).

In the studies conducted for different purposes with switchgrass cultivars, it was reported that the ADF and NDF ratios varied between $21.3 \%-66.9 \%$ and $57.6 \%-86.5 \%$, respectively (Madakadze et al., 1999; Sanderson et al., 1999; Soylu et al., 2010; Mantino et al., 2017; Mohammed and Desta, 2017).

\section{Fleig score (FS)}

One of the most important criteria used in the determination of the quality of silage feed is the FS, which is calculated based on the regression equation between DM and pH of the silage (Woolfort, 1984; Kilıç, 1986; Geren, 2001). In terms of the FS, the difference between the silage of the switchgrass cultivars examined in the study was found to be statistically significant at $p<0.01$ level. Although the highest FS was determined in the BoMaster (144.7 points) cultivar, the difference between the Alamo, Trailblazer, Cave in Rock, and Long Island cultivars was found to be statistically insignificant. The lowest FS was found in the Shawnee cultivar by 88.6 (Table 5).

Table 5. Fleig scores of the silage obtained from switchgrass cultivars*

\begin{tabular}{c|c}
\hline Cultivars & FS \\
Kanlow & $111.9 \mathrm{~b}$ \\
Shelter & $105.5 \mathrm{bc}$ \\
Shawnee & $88.6 \mathrm{c}$ \\
BoMaster & $144.7 \mathrm{a}$ \\
Alamo & $134.2 \mathrm{a}$ \\
Crailblazer & $130.9 \mathrm{a}$ \\
Long Island & $144.3 \mathrm{a}$ \\
\hline Fcultivar & $130.6 \mathrm{a}$ \\
\hline CV $\%)$ & $30.658^{* *}$ \\
\hline$*:$ The difference between the means indicated by the same letter is not significant, \\
$*$ p $<0.01$ is significant within error limits, CV: Coefficient variation
\end{tabular}

In the study, when the FS of the silage of switchgrass cultivars ranging from 88.6-144.7 were evaluated according to Table 3, the quality of silage obtained from switchgrass cultivars was found to be "very good". When the FS calculated by considering the DM and $\mathrm{pH}$ contents of silo feeds is compared with the studies carried out in corn (Geren, 2000, 2001; Demirel et al., 2001; Kavut and Soya, 2012), it can be said that similar results have been achieved.

When the desired $\mathrm{pH}$ and DM ratio is ensured in the silo feed, the FS is also high. In our study, it was observed that the FS of all switchgrass cultivars other than the Shawnee cultivar was above 100 (Table 5). Similar results were also achieved in corn (150.5 points) and sorghum (123.3 points) silage by Öten et al. (2016) and in corn (104.2 points) silage by Seydoşoğlu (2017).

\section{Physical properties of the silage of switchgrass cultivars}

The scores of the physical properties (odor, structure, and color) of the silage obtained from switchgrass cultivars, the DLG score, and the silage quality class according to physical properties are presented in Table 6. 
While the difference between the cultivars in terms of odor and structure was found to be statistically significant at $\mathrm{p}<0.01$ level, the difference between the cultivars in terms of color was found to be insignificant. The Long Island cultivar had the highest score in terms of all three physical properties. Nevertheless, the difference between the Long Island cultivar and the Cave in Rock cultivar in terms of odor and the difference between the Cave in Rock, Alamo, BoMaster, and Shelter cultivars in terms of the structure were found to be statistically insignificant (Table 6). In the silage made with switchgrass, the fact that the physical appearance was largely preserved, especially in terms of the above-mentioned cultivars producing high scores, indicates that successful silage can be achieved with switchgrass plant. On the other hand, silage quality also varies depending on the fermentation process (Geren, 2001). Therefore, as it was also indicated by Comberg (1974) and Akyıldız (1984), the silage feed of an ideal quality may have a pleasant acidic, slightly sour and aromatic odor resulting from the odor of the products produced by LA bacteria. Furthermore, it was reported that the physical structure of the feed (Geren, 2001) and the color of the silage (Woolfort, 1984) could be largely preserved if the silage was made well.

Table 6. Mean scores of the physical properties of the silage obtained from switchgrass cultivars, and the quality class*

\begin{tabular}{c|c|c|c|c|c}
\hline Cultivars & Odor & Structure & Color & DLG score & Quality class \\
\hline Kanlow & $8.0 \mathrm{e}$ & $2.0 \mathrm{~b}$ & 1.3 & $11.3 \mathrm{~d}$ & Medium \\
Shelter & $8.7 \mathrm{de}$ & $3.3 \mathrm{ab}$ & 1.3 & $13.3 \mathrm{~cd}$ & Medium \\
Shawnee & $9.3 \mathrm{cde}$ & $2.0 \mathrm{~b}$ & 1.3 & $12.7 \mathrm{~d}$ & Medium \\
BoMaster & $11.3 \mathrm{bc}$ & $3.3 \mathrm{ab}$ & 1.3 & $16.0 \mathrm{bc}$ & Good \\
Alamo & $10.7 \mathrm{bcd}$ & $4.0 \mathrm{a}$ & 1.7 & $16.3 \mathrm{~b}$ & Good \\
Trailblazer & $10.3 \mathrm{bcd}$ & $2.0 \mathrm{~b}$ & 1.0 & $13.3 \mathrm{~cd}$ & Medium \\
Cave in Rock & $12.0 \mathrm{ab}$ & $4.0 \mathrm{a}$ & 1.7 & $17.7 \mathrm{ab}$ & Very good \\
Long Island & $13.7 \mathrm{a}$ & $4.0 \mathrm{a}$ & 2.0 & $19.7 \mathrm{a}$ & Very good \\
\hline $\mathrm{F}_{\text {cultivar }}$ & $18.58^{* *}$ & $7.40^{* *}$ & 1.06 & $24.78^{* *}$ & \\
\hline $\mathrm{CV}(\%)$ & 7.09 & 12.85 & 6.08 & 6.55 & \\
\hline
\end{tabular}

*: The difference between the means indicated by the same letter in the same column is not significant,

**: $\mathrm{p}<0.01$ is significant within error limits, $\mathrm{CV}$ : Coefficient variation

When the DLG scores were considered, the highest value was determined in the silage of the Long Island cultivar by 19.7 points, followed by the Cave in Rock cultivar by 17.7 points. The lowest DLG score was found in the Kanlow (11.3 points) and Shawnee (12.7) cultivars. This difference between the cultivars in terms of DLG was found to be statistically significant at $p<0.01$ level. According to the classification of the DLG score obtained by adding the odor, structure, and color scores of the silage (Anonymous, 1987) in the evaluation of the physical properties of silage feed, it was observed that "good" quality silage was obtained from the BoMaster and Alamo cultivars and "very good" quality silage was obtained from the Long Island and Cave in Rock cultivars (Table 6).

The harvest time (10-15 days after the beginning of flowering) was effective in obtaining high-quality silage from switchgrass cultivars in terms of physical properties. In the silage study carried out with corn and sorghum plants in a different flowering period (Rafiuddin et al., 2016), it was reported that the color, odor, structure, and total physical score values of the silage increased from early flowering to the full flowering period (as the developmental stage progresses), and the silage quality class became 
"very good" from a physical aspect. The improvement in the physical properties of silage as the harvest period progressed was also indicated by Khan et al. (2011) and Khan et al. (2012). Moreover, it is considered that the high score in physical properties was affected by low $\mathrm{pH}$, high DM, and high LA values, as it was also indicated by Rafiuddin et al. (2016).

With respect to the switchgrass plant, there was no study on the physical characteristics of silage. However, when compared to the properties of silage made with plants such as corn, sorghum, sorghum x sudangrass hybrid which are physiologically C4 plants such as switchgrass plant, it was observed that the results similar to the results of our study were achieved. In the silage studies carried out with these $\mathrm{C} 4$ plants (Geren, 2000; Güney et al., 2010; Öten et al., 2016; Rafiuddin et al., 2016; Seydoşoğlu, 2017), it was reported that the physical score of silage odor varied between 8-14, the silage structure varied between 2-4 points, and the silage color varied between 1-2, and good and/or very good quality silage was obtained according to the DLG score, as in the switchgrass cultivars in the results of our study. Furthermore, our results indicating that cultivars had no significant effects on silage color were found to be consistent with the results obtained by Geren (2000), Güney et al. (2010), Kavut and Soya (2012), and Seydoşoğlu (2017).

\section{Conclusions}

According to the study results, it was determined that the Long Island and Cave in Rock cultivars came to the forefront in terms of silage quality and that the BoMaster, Alamo, and Trailblazer cultivars could also be used successfully in silage production. In this study carried out with switchgrass which is used as an alternative plant for the production of bioethanol and forage plants in the world but is a new plant for Turkey, it was concluded that promising results were achieved in terms of silage quality and it could be an alternative source of roughage for livestock businesses. Since switchgrass is a perennial plant with 10 to 15 years lifespan, it would be a longterm resource for silage production.

Acknowledgements. This study was produced from the first author's master's thesis accepted by the Graduate School of Natural and Applied Science of Siirt University. The study was supported by the Scientific Research Projects Coordinatorship of Siirt University with the project code 2017-SIÜFEB-85.

\section{REFERENCES}

[1] Açıkgöz, N., Açıkgöz, N. (2001): Common mistakes in the statistical analyzes of agricultural experiments I. Single factorials. - Anadolu 11(1): 135-147. (In Turkish).

[2] Açıkgöz, E., Turgut, İ., Filya, İ. (2002): Silage Plants Growing and Silage Making. Hasat Yayınları, İstanbul, Turkey. (In Turkish).

[3] Akyıldız, A. R. (1984): Foods Information Laboratory Guide. - University of Ankara, Faculty of Agriculture, Publication No: 893, Application Guide: 213, Ankara, Turkey. (In Turkish).

[4] Alçiçek, A., Özkan, K. (1997): Determination of silage quality by physical and chemical methods in silo feeds. - Turkey I. Silage Congress, Bursa, Turkey, pp. 241-247. (In Turkish). 
[5] Ameen, A., Tang, C., Liu, J., Han, L., Xie, G. H. (2018): Switchgrass as forage and biofuel feedstock: Effect of nitrogen fertilization rate on the quality of biomass harvested in late summer and early fall. - Field Crops Research 235: 154-162.

[6] Anderson, B., Ward, J. K., Vogel, K. P., Ward, M. G., Gorz, H. J., Haskins, F. A. (1988): Forage quality and performance of yearlings grazing switchgrass strains selected for differing digestibility. - University of Nebraska-Lincoln, Agronomy-Faculty Publications, 308p.

[7] Anonymous (1987): Bewertung von Grünfutter, Silage und Heu. - Deutsche Landwirtschafts-Gesellschaft (DLG), DLG Merkblatt 224, Frankfurt.

[8] Anonymous (1992): Procedures For Collecting Soil Samples and Methods of Analysis For Soil Survey. - Soil Survey Staff, Soil Survey Investigations Report No. 42, Washington DC, USA.

[9] Anonymous (1993): Bestimmung des pH-Wertes. - In: Die chemischen Untersuchungen von Futtermitteln. Teil 18 Silage. Abschnit 18.1 Bestimmung des pH-Wertes., Methodenbuch Bd. III., VDLUFAVerlag, Darmstadt.

[10] Anonymous (2017): Siirt Province Climate Data. - T.C. Ministry of Agriculture and Forestry, General Directorate of Meteorology, Turkey.

[11] Anonymous (2018): WinISI 4 Calibration Software: Ground, Expandable Equation Packages. - (http://www.winisi.com/product_calibrations.htm) (Date of Access: 20.05.2018).

[12] Arslan, M., Çakmakçı, S. (2011): Comparison of corn (Zea mays) and sorghum (Sorghum bicolor) silages mixed with different plants. - Mediterranean Agricultural Sciences 24(1): 47-53. (In Turkish).

[13] Arslan, M., Erdurmuş, C., Öten, M., Aydınoğlu, B., Çakmakçı, S. (2017): Quality charecteristics of sorghum and some plants silages mixed at different rates. - Journal of Tekirdag Agricultural Faculty 14(02): 34-41. (In Turkish).

[14] Barnes, R. F., Miller, D. A., Nelson, C. J. (1995): Forages, Volume II: The science of grassland agriculture. -5 th Ed. Iowa State Univ. Press. Ames., 357p.

[15] Belanger, G., Savoie, P., Parent, G., Claessens, A., Bertrand, A., Tremblay, G. F., Masse, D., Gilbert, Y., Babineau, D. (2012): Switchgrass silage for methane production as affected by date of harvest. - Canadian Journal of Plant Science 92: 1187-1197.

[16] Bolsen, K. K., Ashbell, G., Weinberg, Z. G. (1996): Silage fermentation and silage additives. - Ajas 9(5): 483-493.

[17] Brodowska, M. S., Muszyński, P., Haliniarz, M., Brodowski, R., Kowalczyk-Juśko, A., Sekutowski, T., Kurzyna-Szklarek, M. (2018): Agronomic aspects of switchgrass cultivation and use for energy purposes. - Applied Ecology and Environmental Research 16(5): 5715-5743.

[18] Brogna, N., Pacchioli, M. T., Immovilli, A., Ruozzi, F., Ward, R., Formigoni, A. (2009): The use of near-infrared reflectance spectroscopy (NIRS) in the prediction of chemical composition and in vitro neutral detergent fiber (NDF) digestibility of Italian alfalfa hay. - Italian Journal of Animal Science 8(Suppl. 2): 271-273.

[19] Brunken, J. N., Estes, J. R. (1975): Cytological and morphological variation in Panicum virgatum L. - The Southwestern Naturalist 19(4): 379-385.

[20] Bulgurlu, Ş., Ergül, M. (1978): Physical, Chemical and Biological Analysis Methods of Feed. - University of Ege, Faculty of Agriculture, Publication No: 127, Ege University Printing House, Bornova-İzmir, Turkey, pp. 58-76. (In Turkish).

[21] Canale, A., Valente, M. E., Ciotti, A. (1984): Determination of volatile carboxylic acids $\left(\mathrm{C}_{1}-\mathrm{C}_{5 \mathrm{i}}\right)$ and lactic acid in aqueous acid extracts of silage by high performance liquid chromatography. - Journal of the Science of Food and Agriculture 35: 1178-1182.

[22] Canbolat, Ö., Karasu, A., Bayram, G., Filya, İ., Kamalak, A. (2016): The effect of sowing density on the nutritive value, silage quality characteristics and nutrient yields of non stover sweet corn (Zea mays L. saccharata Sturt.). - Journal of Agricultural Faculty of Uludag University 30(1): 101-112. (In Turkish). 
[23] Casler, M. D., Boe, A. R. (2003): Cultivar x environment interactions in switchgrass. Crop Sci. 43: 2226-2233.

[24] Cassida, K. A., Muir, J. P., Hussey, M. A., Read, J. C., Venuto, B. C., Ocumpaugh, W. R. (2005): Biofuel component concentrations and yields of switchgrass in South Central U.S. environmental. - Crop Sci. 45: 682-692.

[25] Catchpoole, V. R., Henzell, E. F. (1971): Silage and silage-making from Tropical Herbage species. - Herbage Abstracts 41(3): 213-221.

[26] Church, D. C. (1986): Feed and Feeding. - Prentice Hill A Division of Simon and Schuster., Inc. Englewood Cliffs, NY, United Stated of America.

[27] Comberg, G. (1974): Gärfutter: Betriebswirtschaft, Erzeugung, Verfütterung. - Verlag Eugen Ulmer Stuttgart, Gerokstraße 19, Printed in Germany, ISBN: 3-8001-4321-6, 260p.

[28] Çakmak, B., Yalçın, H., Bilgen, H. (2013): The effect of packing pressure and storage duration on the crude nutrient content and the quality of silages made from green and fermented corn. - Journal of Agricultural Sciences 19: 22-32. (In Turkish).

[29] Çayıroğlu, H., Coşkun, İ., Şahin, A. (2016): Factors affecting the aerobic stability of silage and improvement strategies. - Alınteri 31(B): 91-97. (In Turkish).

[30] Çiçek, F. (2017): The determination of G.D.D. for different morphological stages and physiological characteristics of cutting times of switchgrass varieties (Panicum virgatium L.). - Ms Thesis, The Graduate School of Natural and Applied Science of Selçuk University, Konya, Turkey, 73p. (In Turkish).

[31] Danley, M. M., Vetter, R. L., Wedin, W. F. (1973): Modified laboratory silo unit for studying the fermentation of corn (Zea mays L.) grain. - Agronomy Journal 65: 621-624.

[32] Davis, D., Pas, G. A., Liewellyn, D. A., Lea, K., Smith, S. R. (2018): Case study: Intake and apparent digestibility by beef calves of Alamo and Cave-in-Rock switchgrass cultivars harvested as hay at 3 different maturities. - The Professional Animal Scientist 34(5): 469-473.

[33] Demirel, M., Cengiz, F., Çelik, S., Erdoğan, S. (2001): A study on degradability in rumen and silage quality of mixture of corn and hungarian vetch grown in Van ecological conditions. - J. Agric. Sci. 11(1): 69-78. (In Turkish).

[34] Deswysen, A. G., Dutilleud, P., Godfrin, J. P., Ellis, W. C. (1993): Nycterohemeral eating and ruminating patterns in heifers fed grass or corn silage: analysis by finite fourier transform. - J. Anim. Sci. 71: 2739-2747.

[35] Elbersen, H. W., Christian, D. G., El Bassen, N., Bacher, W., Sauerbeck, G., Aleopoulou, E., Sharma, N., Piscioneri, I., De Visser, P., Van Den Berg, D. (2001): Switchgrass variety choice in Europe. - Aspects of Applied Biology 65: 21-28.

[36] Ergün, A., Tuncer, Ş. D., Çolpan, İ., Yalçın, S., Yıldız, G., Küçükersan, M. K., Küçükersan, S., Şehu, A., Saçakl1, P. (2013): Feed, Feed Hygiene and Technology. Ankara University, Faculty of Veterinary Medicine, Extended 5th Edition, Ankara, Turkey, 448p. (In Turkish).

[37] Filya, İ., Ashbell, G., Hen, Y., Weinberg, Z. G. (2000): The effect of bacterial inoculants on the fermentation and aerobic stability of whole crop wheat silage. - Animal Feed Science and Technology 88(1-2): 39-46.

[38] Filya, İ. (2001): Silage Technology. - Uludăg University, Faculty of Agriculture, Department of Animal Science, Bursa, Turkey. (In Turkish).

[39] Geren, H. (2000): Investigations on the effect of sowing dates on the forage yields and agronomical characteristics related to silage of different maize (Zea mays L.) cultivars grown as main and second crops. - PhD Thesis, The Graduate School of Natural and Applied Science of Ege University, İzmir, Turkey, 251p. (In Turkish).

[40] Geren, H. (2001): Effect of sowing dates on silage characteristics of different maize cultivars grown as second crop under Bornova conditions. - Journal of Agriculture Faculty of Ege University 38(2-3): 47-54. (In Turkish). 
[41] Geren, H., Kavut, Y. T. (2009): An investigation on comparison of Sorghum (Sorghum sp.) species with corn (Zea mays L.) grown under second crop production. - Journal of Agriculture Faculty of Ege University 46(1): 9-16. (In Turkish).

[42] Geren, H., Kavut, Y. T., Avcioğlu, R. (2011): A preliminary study on ensilability characteristics and yield and other related traits of elephant grass (Miscanthus $\mathrm{x}$ giganteus) under Mediterranean climatic conditions. - Journal of Agriculture Faculty of Ege University 48(3): 203-209. (In Turkish).

[43] Göhl, B. (1981): Tropical Feeds: Feeds Information Summaries and Nutritive Values. Food and Agriculture Organization of the United Nations, Rome, 529p.

[44] Güney, E., Tan, M., Dumlu Gül, Z., Gül, İ. (2010): Determination of yield and silage quality of some maize cultivars in Erzurum conditions. - Journal of Agricultural Faculty of Atatürk University 41(2): 105-111. (In Turkish).

[45] Gürsoy, E., Macit, M. (2014): Determination of in vitro gas production parameters of some grass forages grown as naturally in the pastures of Erzurum. - YYU J Agr Sci 24(3): 218-227. (In Turkish).

[46] Hart, S. P. (1990): Effects of altering the grain content of sorghum silage on its nutritive value. - J. Anim. Sci. 68: 3832-3842.

[47] Hopkins, A. A., Vogel, K. P., Moore, K. J., Johnson, K. D., Carlson, I. T. (1995): Genotypic variability and genotype xenvironment interactions among switchgrass accessions from the Midwestern USA. - Crop Sci. 35: 565-571.

[48] Hopkins, A. A., Taliaferro, C. M., Murphy, C. D., Christian, D. (1996): Chromosome number and nuclear DNA content of several switchgrass populations. - Crop Sci. 36: 1192-1195.

[49] Ileri, O., Budaklı Carpıcı, E., Erbeyi, B., Avcı, S., Koc, A. (2018): Effect of sowing methods on silage yield and quality of some corn cultivars grown in second crop season under irrigated condition of Central Anatolia, Turkey. - Turk J Field Crops 23(1): 72-79. DOI: $10.17557 / \mathrm{tjfc} .424379$.

[50] Isnandar, U. R., Chuzaemi, S., Sutariningsih, E., Yusiati, L. M. (2010): The role of lactic acid bacteria on silage duration process and rumen content silage quality. - The $5^{\text {th }}$ International Seminar on Tropical Animal Production, Community Empowerment and Tropical Animal Industry, October 19-22, Yogyakarta, Indonesia, pp. 243-249.

[51] Jiang, Q., Webb, S. L., Bhandari, H. S., Bouton, J. H., Saha, M. C. (2019): Ecotypic and genotypic effects on regrowth and heading date in switchgrass (Panicum virgatum). Plant Direct 3: 1-9.

[52] Johnson, L. M., Harrison, J. H. (2001): Scientific aspects of silage making. Proceedings, $31^{\text {st }}$ California Alfalfa \& Forage Symposium, 12-13 December, Modesto, CA, UC Cooperative Extension, University of California, Davis.

[53] Kavut, Y. T., Soya, H. (2012): An investigation on the silage quality characteristics of some maize (Zea mays L.) cultivars under Aegean region conditions. - Journal of Agriculture Faculty of Ege University 49(3): 223-227. (In Turkish).

[54] Khan, S. H., Azim, A., Sarwar, M., Khan, A. G. (2011): Effect of maturity on comparative nutritive value and Fermentation characteristic of maize, sorghum and millet silages. - Pak. J. Bot. 43(6): 2967-2970.

[55] Khan, N. A., Tewoldebrhan, T. A., Zom, R. L. G., Cone, J. W., Hendriks, W. H. (2012): Effect of corn silage harvest maturity and concentrate type on milk fatty acid composition of dairy cows. - J. Dairy Sci. 95: 1472-1483.

[56] Kilıç, A. (1986): Silo Feed (Teaching, Learning and Application Suggestions). - Ege University, Faculty of Agriculture, Department of Animal Science, Bilgehan Printing House, İzmir, Turkey, 327p. (In Turkish).

[57] Kılıç, A. (2006): Determination of Quality in Roughage. - Hasat Publishing, İstanbul, Turkey. (In Turkish).

[58] Kiermeier, F., Renner, E. (1963): Der pH- Wert Ais Kriterium der Verwendbarkeit von Silage für die Milchvieh Fütterung. - Das Wirtschaftseiq, Futterq: 106-113. 
[59] Kimura, E., Fransen, S. C., Collins, H. P., Stanton, B. J., Himes, A., Smith, J., Guy, S. O., Johnston, W. J. (2018): Effect of intercropping hybrid poplar and switchgrass on biomass yield, forage quality, and land use efficiency for bioenergy production. - Biomass and Bioenergy 111: 31-38.

[60] Lee, D. K., Owens, V. N., Doolittle, J. J. (2007): Switchgrass and soil carbon sequestration response to ammonium nitrate, manure, and harvest frequency on Conservation Reserve Program land. - Agron J 99(2): 462-468.

[61] Lemus, R., Brummer, E. C., Moore, K. J., Molstad, N. E., Burras, C. L., Barker, M. F. (2002): Biomass yield and quality of 20 switchgrass populations in southern Iowa, USA. - Biomass and Bioenergy 23: 433-442.

[62] Luginbuhl, J. M., Pond, K. R., Burns, J. C., Fisher, D. S. (2000): Intake and chewing behavior of steers consuming switchgrass preserved as hay or silage. - American Society of Animal Science 78: 1983-1989.

[63] Ma, Y., An, Y., Shui, J., Sun, Z. (2011): Adaptability evaluation of switchgrass (Panicum virgatum L.) cultivars on the Loess Plateau of China. - Plant Science 181: 638-643.

[64] Madakadze, I. C., Stewart, K. A., Peterson, P. R., Bruce, E., Coulman, E., Smith, D. L. (1999): Switchgrass biomass and chemical composition for biofuel in Eastern Canada. Agronomy Journal 91: 696-701.

[65] Mantino, A., Ragaglini, G., Nassi o di Nasso, N., Cappucci, A., Mele, M., Bonari, E. (2017): Suitability of switchgrass (Panicum virgatum L.) as a forage crop in the Mediterranean area. - Grassland Science in Europe 22: 194-196.

[66] McDonald, P., Henderson, A. R., Heron, S. J. E. (1991): The Biochemistry of Silage. 2nd Edition, Chalcombe Publications, Printed in Great Britain by Cambrian Printers Ltd, Aberystwyth, ISBN: 0-948617-22-5, 327p.

[67] McLaughlin, S. B., Kszos, L. A. (2005): Development of switchgrass (Panicum virgatum) as a bioenergy feedstock in the United States. - Biomass Bioenergy 28: 515535.

[68] Milenković, J., Stanisavljević, R., Marković, J., Petrović, M., Vasić, T., Anđelković, S., Terzić, D. (2018): Biomass quality of different genotypes of switchgrass (Panicum virgatum L.) for animal feed. - Journal on Processing and Energy in Agriculture 22(3): 122-124.

[69] Missaoui, A. M., Bouton, J. H., Paterson, A. H. (2006): Molecular markers for the classification of switchgrass (Panicum virgatum L.) germplasm and to assess genetic diversity in three synthetic switchgrass populations. - Gen. Res. Crop Evol. 53: 12911302.

[70] Mohammed, Y. A., Desta, K. G. (2017): Nutrient source affected quality biomass production of early harvest switchgrass for animal feed. - International Journal of Agriculture and Environmental Research 3(2): 2546-2555.

[71] Mohd-Setapar, S. H., Abd-Talib, N., Aziz, R. (2012): Review on crucial parameters of silage quality. - APCBEE Procedia 3: 99-103.

[72] Muir, J. P., Sanderson, M. A., Ocumpaugh, W. R., Jones, R. M., Reed, R. L. (2001): Biomass production of 'Alamo' switchgrass in response to nitrogen, phosphorus, and row spacing. - Agron J 93(4): 896-901.

[73] Nelson, D. W., Sommers, L. E. (1982): Total Carbon, Organic Carbon and Organic Matter. - In: Page, L. A., Miller, R. H., Keeney, D. R. (eds.) Methods of Soil Analysis, Part 2. Chemical and Microbiological Methods (2nd ed.) American Society of Agronomy, Madison, pp. 539-579.

[74] Ohmomo, S., Katayama, N., Potacharoen, W., Tanaka, O., Sirianuntapiboon, S., Atthasampunna, P. (1995): Screening of lactic acid bacteria suitable for silage-making in tropical regions. - JARQ 29: 251-256.

[75] Öten, M., Kiremitci, S., Çınar, O. (2016): Determination of silage quality of some forage crops and mixtures by different methods. - J. of AARI 26(2): 33-43. (In Turkish). 
[76] Özdüven, M. L., Koç, F., Polat, P., Coşkuntuna, L., Başkavak, S., Şamlı, H. E. (2009): Effects of fermentation characteristics and feed value of some maize cultivars ensiled at different stages of maturity. - Journal of Tekirdag Agricultural Faculty 6(2): 121-129. (In Turkish).

[77] Petterson, K. (1988): Ensiling of forages: Factors affecting silage fermentation and quality. - Swedish University of Agricultural Sciences, Department of Animal Nutrition and Management, Uppsala, 46p.

[78] Phillip, L. E., Hidalgo, V. (1989): Voluntary feed intake, acıd-base balance and partitioning of urinary nitrogen in lambs fed corn silage with added sodium bicarbonate or sodium sesquicarbonate. - J. Anim. Sci. 67: 2116-2122.

[79] Piscioneri, I., Pignatelli, V., Palazzo, S., Sharma, N. (2001): Switchgrass production and establishment in the Southern Italy climatic conditions. - Energy Conversion and Management 42(18): 2071-2082.

[80] Polat, C., Koç, F., Özdüven, M. L. (2005): The effects of lactic acid bacteria and lactic acid bacteria+enzyme mixture silage inoculants on maize silage fermentation and nutrient digestibility in lambs. - Journal of Tekirdag Agricultural Faculty 2(1): 13-22. (In Turkish).

[81] Quinn, J. A. (1969): Variability among high plains populations of Panicum virgatum. Bulletin of the Torrey Botanical Club 96(1): 20-41.

[82] Quinn, J. A., Wetherington, J. D. (2002): Genetic variability and phenotypic plasticity in flowering phenology in populations of two grasses. - The Journal of the Torrey Botanical Society 129(2): 96-106.

[83] Rafiuddin, Abdullah, M., Javed, K., Jabbar, M. A., Shahid, M. Q., Jan, P. S., Khan, M. A., Ramzan, M., Hamdullah. (2016): Impact of flowering stage on nutritive value, physical quality and digestibility of silages made from cereal fodders. - Applied Ecology And Environmental Research 14(5): 149-157.

[84] Reeves, J. B., Blosser, T. H., Colenbrander, V. F. (1989): Near infrared reflectance spectroscopy for analyzing undried silage. - J. Dairy Sci. 72: 79-88.

[85] Rohweder, D. A., Barnes, R. F., Jorgensen, N. (1978): Proposed hay grading standards based on laboratory analyses for evaluating quality. - Journal of Animal Science 47(3): 747-759.

[86] Roth, G. W. (2001): Corn Silage Productionand Management. - College of Agricultural Sciences. Agricultural Research and Coop. Extension, Agronomy Facts 18.

[87] Sanderson, M. A., Read, J. C., Reed, R. L. (1999): Harvest management of switchgrass for biomass feedstock and forage production. - Argon. J. 91: 5-10.

[88] Sanderson, M. A., Burns, J. C. (2010): Digestibility and intake of hays from upland switchgrass cultivars. - Crop Science 50: 2641-2648.

[89] Sena, K. L., Goff, B., Davis, D., Smith, S. R. (2018): Switchgrass growth and forage quality trends provide insight for management. - Crop, Forage \& Turfgrass Management 4(1): 170053. doi:10.2134/cftm2017.08.0053.

[90] Seydoşoğlu, S. (2017): Investigation of the effects of different sowing times of different varieties on second crop maize silage yield and quality. - PhD Thesis, Institute of Natural and Applied Sciences University of Dicle, Diyarbakır, Turkey, 201p. (In Turkish).

[91] Soylu, S., Sade, B., Öğ̈ut, H., Akınerdem, F., Babaoğlu, M., Ada, R., Eryılmaz, T., Öztürk, Ö., Oğuz, H. (2010): Investigation of the possibilities of growing switchgrass (Panicum virgatum $\mathrm{L}$.) as an alternative biofuel and silage plant for Turkey. - TÜBİTAK Project Finally Report, Project No: TOVAG-107 O 161, Konya, Turkey. (In Turkish).

[92] Soylu, S. (2012): Investigation of agronomic techniques of switchgrass (Panicum virgatum L.) as an alternative biofuel plant in Turkey. - Journal of Agricultural Machinery Science 8(3): 257-263. (In Turkish).

[93] Sucu, E., Filya, İ. (2006): Effects of homofermentative lactic acid bacterial noculants on the fermentation and aerobic stability characteristics of low dry matter corn silages. Turkish Journal of Veterinary and Animal Sciences 30: 83-88. 
[94] Van Soest, P. J. (1994): Nutritional Ecology of the Ruminant (2nd Ed.). - Ithaca, N.Y. Cornell University Press.

[95] Van Wambeke, A. R. (2000): The Newhall Simulation Model for Estimating Soil Moisture and Temperature Regimes. - Department of Crop and Soil Sciences, Cornell University, Ithaca, NY.

[96] Vogel, K. P., Brejda, J. J., Walters, D. T., Buxton, D. R. (2002): Switchgrass biomass production in the midwest USA: harvest and nitrogen management. - Agron J 94(3): 413420.

[97] Vogel, K. P. (2004): Switchgrass. - In: Moser, L. E., Sollenberger, L., Burson, B. (eds.) Warm-season (C4) grasses. Madison, WI: ASA, CSSA, and SSSA, pp. 561-588.

[98] Weinberg, Z. G., Ashbell, G. (2003): Engineering aspects of ensiling. - Biochemical Engineering Journal 13: 181-188.

[99] Wolf, D. D., Fiske, D. A. (1995): Planting and Managing Switchgrass for Forage, Wildlife, and Conservation. - Virginia Polytechnic Institute and State University, Virginia Cooperative Extension Publication, Blacksburg, VA, pp. 418-513.

[100] Woolfort, M. K. (1984): The Silage Ferment. - Grassland Research Inst, Hurley, England, 350p.

[101] Zhao, X., Liu, J., Liu, J., Yang, F., Zhu, W., Yuan, X., Hua, Y., Cui, Z., Wang, X. (2017): Effect of ensiling and silage additives on biogas production and microbial community dynamics during anaerobic digestion of switchgrass. - Bioresource Technology 241: 349359. 